\title{
日本知能情報ファジィ学会誌 総目次
}

第 24 巻 第 1 号 第 6 号 平成 24 年 $2 \cdot 4 \cdot 6 \cdot 8 \cdot 10 \cdot 12$ 月

号 ページ

\section{巻頭言}

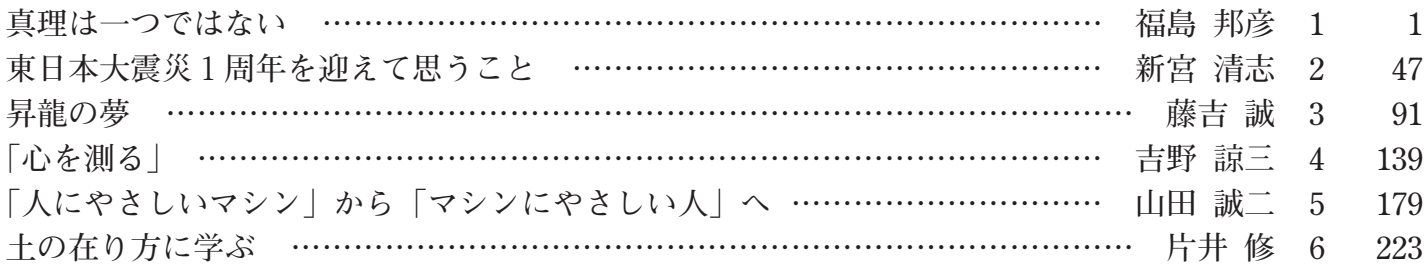

\section{追悼}

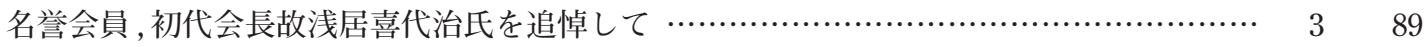

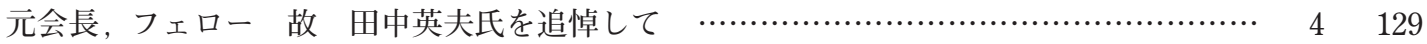

浅居先生の訃報に寄せて ……………... 日本知能情報フアジィ学会会誌編集委員会 44131

\section{特 集}

「脳システムと身体知獲得」

「脳システムと身体知獲得」の企画に関して …………... 三好 哲也・田中一男・林 勲 1235 「データマイニング」

「データマイニング」特集にあたって ………...................................... 新美 礼彦 $3 \quad 120$

「心を測る」

「心を測る」特集にあたって

山下 利之 4

「第 16 回曖味な気持ちに挑むワークショップ選抜論文」

「第 16 回曖昧な気持ちに挑むワークショップ選抜論文」特集にあたって…… 高萩 栄一郎 44171 「ヒトと関わり合う知的システム」

「ヒトと関わり合う知的システム」特集にあたって 前田 陽一郎・片上 大輔 5 211 「メタヒューリスティックアルゴリズムに基づく最適化の進展」

「メタヒューリスティックアルゴリズムに基づく最適化の進展」特集にあたって

\section{解 説}

身体知獲得のための脳情報処理と言語指示

古川 康一 1

音楽する脳 藤波 努 18

RoboCup サッカーシミュレーションリーグ

解説：2011年世界大会レポートと今後の展望 秋山 英久·中島 智晴 114

ファジィ推論を用いた道路交通シミュレータの開発 本多 中二·佐藤 洋介 248

安全とファジィ〜どこまでやったら安全か〜 向殿 政男 255

ファジィ数 I 稲井田 次郎 392

データベースの初歩と, 現在の活用例 甲木 洋介 3100

心を測る手法とツール 山下 利之 4140

ファジィ数 II 稲井田 次郎 4147

ヒトと共生できる未来の知的システムを目指して

〜知能システムから人間共生システムへのパラダイムシフト〜 前田 陽一郎 5180 ヒトと関わり合う知的システムが創り出す䨌囲気のイノベーション 片上 大輔 5188 
探索に基づいたソフトウェア工学：SBSE

ーソフトウェア工学に打けるメタヒューリスティックスの援用ー 半田 久志 6224

ファジィ数 IV

稲井田 次郎 6230

\section{報 告}

SOFT SNS 動画コンテスト 2011 報告

第 16 回曖昧な気持ちに挑むワークショップ（Heart\&Mind2011）開催報告…… 藤本 勝成 121

ISIS 2011 参加報告 岩下 志乃 123

「論文部分のオンライン化」にあたって ……… 日本知能情報ファジィ学会会誌編集委員会 1125

デザインのプロセス 安藤 萌香 126

NLMUA 2011 参加報告 藤本 勝成 263

第 7 回ファジィ学問塾開催報告 渡邊 俊彦・永島 謙一 265

IEEE GrC 2011 参加報告 工藤 康生 267

SNS 対談ソーシャルメディア研究所熊坂仁美代表 Part1「学会と SNS 活用」 . 熊坂 仁美・高木 友博 2

ICMLA 2011 参加報告 岩元 優希・野津 亮

第 22 回ソフトサイエンス・ワークショップ開催報告 小田 哲久 3108

第 24 回 SCRUM 開催報告 柴田 淳司 4 155

第 38 回ファジィワークショップ開催報告 山下 利之 4157

WCCI 2012 参加報告 大竹 博・本多 克宏 5200

FSS 2012 開催報告 中村 剛士 6238

第 25 回ソフトコンピューティング若手研究会開催報告 阪口 智彦 6240

\section{書 評}

山口昌哉 (著)：

「カオスとフラクタル」

（社）電気学会進化技術応用調査専門委員会（編集）著：

「進化技術ハンドブック第 II 巻応用編：情報・通信システム」 $\ldots \ldots \ldots \ldots \ldots$ 折登 由希子 2 中村太郎 (著) :

「図解人工筋肉 ソフトアクチュエータが拓く世界」 鈴木 秀和 3

Ed Burnette（著），日本Androidの会（監訳），長尾 高弘（翻訳）：

「初めての Android 第 3 版」 秋口悛輔 4

John Shawe - Taylor, Nello Cristianini (著)，大北剛（訳）：

「カーネル法によるパターン解析」

三河 正彦 5

平井有三 (著) :

「はじめてのパターン認識」

山崎 洋一 6

\section{用語解説}

$\alpha$ - GEMII ( $\alpha$ - Level-Set and Generalized-Mean Based Inference)

上原 清彦 128

マルチ能力 : MI (Multiple Intelligences)

Type- 2 ファジィ集合 (Type- 2 Fuzzy Set)

Type- 2 ファジィ推論（Type- 2 Fuzzy Inference） 
マイクロサッカード（microsaccade）

谷部 好子 5

205

不確実性下の意思決定 (Decision - making under uncertainty)

山田 耕一 5205

NUI ( Natural User Interface)

井関文一 6243

ソーシャルネットワークマイニング（Social Network Mining）

新美 礼彦 6243

\section{論文概要}

Vol.24, No.1

$36 \quad 36$

Vol.24, No.2

37

83

Vol.24, No.3

33

121

Vol.24, No.4

44

172

Vol.24, No.5

35

213

Vol.24, No.6

27

249

\section{特集論文}

\section{[原著論文]}

前庭感覚刺激を用いた歩行誘導効果とそれに影響を及ぼす行動決定過程のモデル化

特異值分解による運動動作の特徴獲得

渡邊 紀文・三門 裕明・大森 隆司 11501

特異スペクトル変換による動作変化点列を用いた動作解析法

徳永 寿慧・金田 さやか・中西 弘明・椹木 哲夫 1

手先力制御における筋シナジーの抽出およびロボットへの実装

………고ン ハン・はざ田 政利・前田 大輔・木村 真理子・宮崎 文夫・平井 宏明 1

536

チェロのスピッカート奏法の習得について

古川 康一・升田 俊樹・西山 武繁 1

545

文章入力速度向上を目的とした P300 speller に対する入力文字予測システムの実装とその検討

継岡 恭子・高橋 弘武・吉川 大弘・古橋 武 1

インタラクティブサウンド生成システムのための脳波特徴解析による

リラクゼーション効果の検証

一井 亮介・前田 陽一郎・高橋 泰岳 1 動的環境に適応するマルチロボットの動的フォーメーション

安田 寛·久保田 直行 1

強化学習と情動学習に基づく意思決定法：利己的な判断による協調行動の創発

$$
\text { 三澤 秀明・松田 充史・堀尾 恵一 } 1
$$

階層型学習スパイキングニューラルネットワークを用いた行動推定のためのオンライン学習

情報収集のためのテキストデータ集合の再帰的クラスタリング

砂山 渡・濱岡 秀平・奥田 澄 3

697

単語特性辞書を用いた電子揭示板の䨌囲気の同定 濱岡 秀平 砂山渡 3

出力属性の指定と冗長性に基づくファジィ相関ルールの抽出 渡邊 俊彦 3

Privacy- Preserving Collaborative Filtering Schemes With Sampling Users

Hiroaki KIKUCHI - Hiroatsu KIZAWA 3

心の硬さの測定とその応用 山下 利之・長縄 久生 4

顔画像間の濃度特徴を用いた表情認識

中村 宗広・梶原 祐輔・村田 裕章・木村 春彦 4

多人数に基づく協同問題解決に関する実験的研究のためのプラットフォーム開発

評定尺度法とカーソル運動

林 勇吾・小川 均 4

感情の次元説に基づくファジィメンバシップ関数の顔表情画像からの推定法

椎名 乾平 4858

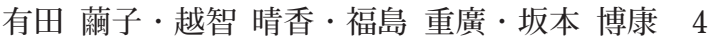


行動と心身状態の関係：携带電話の操作量と睡眠時間と心理検査の比較

多屋 優人・横山 浩之・浅川 徹也・小縣 拓也・鴨 宏一・

熊本 明久 ·宮川大毅・水野(松本) 由子

周辺性に基づくネットワーク形成とその安定性 藤本 勝成 4

割り込み拒否度推定に基づくアンビエント情報提示による円滑なインタラクション開始支援

インタラクティブ情動コミュニケーションに打ける自己組織化マップによる

混合情動行動生成手法 ………………...... 滝 僚平 • 前田 陽一郎・高橋 泰岳 5933 擬似同期を用いた動画共有によるビデオ視聴者の感情高揚

亀井 且有・豊田 晃史・串田 淳一 5

人間の因果推論にみられる認知バイアスに基づいたメロディ生成システム

大村 英史・柴山 拓郎・高橋 達二・涉谷 智志・岡ノ谷一夫・古川聖 5

脳波情報を用いたリラクゼーションサウンド生成システムの構築

前田 陽一郎・一井 亮介・高橋 泰岳 5

脳波特性変化の自動探索によるブレインーコンピューター・インタフェース（BCI）の提案

歩行・顔・身体のソフトバイオメトリック特徵を用いた正面観測個人認証

真部 雄介・齋藤 隆輝・嶋田 弦・菅原 研次 5

988

異質のマルチエージェント間のインタラクションを考慮した学習モデル

動物型 4 脚ロボットに打ける歩容生成と印象評価

張 坤・前田 陽一郎・高橋 泰岳

1002

鈴木 秀和・森崎 巧一・渡邊 香・林原 泰子・西 仁司 51012

決定木を用いた花束の感性ルール抽出と花束提示システムへの応用

グラフ構造の類似性を利用した事例参照型毛筆フォント掠れデザイン

井上 博行・王 冠・西村 美津恵 51023

合田 裕・中村 剛士・加納 政芳 51035

複数の印象辞書を相互利用する印象マイニング手法の提案

熊本 忠彦·河合 由起子·張 建偉 51047

行動予測のための階層型スパイキングニューラルネットワーク

大保 武慶 ·久保田 直行 61071

様々な環境下におけるロボットの行動学習の効率における基礎的検討

曽我 紗知子・小林 一郎 61082

蜜蜂の蜜源選択における閾值調整機能を模した最適化アルゴリズム

古川 まき・森 敏彦・鈴木 泰博 61090

\section{[実践研究論文]}

女性向けフリーマガジンと連動するサイトにおけるユーザの行動分析

大塚 真吾・宮崎 収兄 3

市場分析におけるテキストマイニングを活用したデータマイニングの実践

一生ごみ処理機の市場分析を例としてー

竹内 広宜・杉山 喜昭 · 山口 高平 3

728

\section{[ショートノート]}

遺伝的アルゴリズムを用いた精神関連疾患による不登校児童生徒の診断基準作成システム

村田 裕章・南保 英孝・木村 春彦・梶原 荘平 4895

姿勢推定のための環状放射ネットワークモデル $\quad \cdots . .$. 早瀬 光浩・渡邊 昌平・加納 政芳 541063

ACO による分割統治型TSP近似解法

原 元司・梶野 大輔・堀内 匡 61101

\section{一般論文}

[原著論文]

不完備情報の下での協力ゲームの基礎的考察

栘屋 聡・乾口 雅弘 1601 
ダイエットのための柔軟なレシピ推薦 三野 陽子・小林 一郎

知的な振る舞いの発現に打けるアクチュエータの役割 伊藤 一之・小安 達哉 1

実時間物体追跡に適した動的背景推定法と背景差分法 篠崎 眞太郎・中島 克人 2637

高階化 SOM による形状表現マップ 薬師寺 翔·古川 徹生 2648

ラフ集合の決定ルール可視化による知識発見支援システム

大木 基至・原田 利宣・乾口 雅弘 2

660

笑いを生むことわざすかしの自動生成システム 山根 宏彰・萩原 将文 2

音量の好みを用いた評価值予測によるインタラクティブ ECフィッティングの改善手法

ファジィルールを用いたヒト歩行のモデル化及び 2 脚モデルによるシミュレーション

最近傍を規範とする条件での角度モデルでの包囲

久保 正男・吉村 達郎・山口 明宏・佐藤 浩・松原 隆 3778

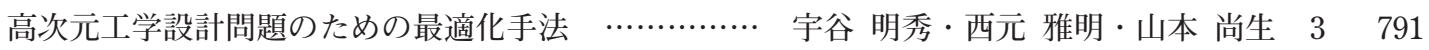

一対比較時の選好再現性に関する確率推論モデル

松下 裕 3803

ブログ記事からのオノマトぺ用例文の自動抽出手法

内田ゆず・荒木 健治・米山 淳 3811

SOHMM を用いた隠れマルコフモデルの状態可視化

梅田 真之・椎名 孝之・今泉 淳・森戸 晋 61119

確率計画法による在庫融通問題

入力履歴の再現による英文法感覚を掴むための学習支援システム

砂山 渡・宮原 和也・川本 佳代 61128

脳波のフラクタル次元解析を用いた感性解析一爽快系シャンプー使用時の検討一

丸山 貴司·橋本 公男 ·上田 俊吾 - 中川 匡弘 61137

矛盾データを有する橋梁点検データからのラフ集合によるルール抽出方法

江本 久雄・八木 英樹·塚本 成昭・宮本 文穂 61154

Efficient On- line Handwritten Signature Verification by Integrating

DTW and Proposed Local Dynamic Similarity Measure

Yusuke MANABE · Basabi CHAKRABORTY 61165

\section{[実践研究論文]}

HOG と Bag of Keypoints を用いた工作機械用制御盤内における物体認識

\section{三吉 建尊・越野 亮・笠原 竹博・上田 芳弘・木村 春彦 4909}

\section{[ショートノート]}

低メモリ学習エージェントのための鎖型状態行動学習

野津 亮・小森 祐希・本多 克宏・市橋 秀友・岩元 優希 2

FCMdd 型線形ファジィクラスタリングによる非ユークリッド関係性データからの

局所的マップ構築 …………………... 山本 剛史・本多 克宏・野津 亮・市橋 秀友 3821

医薬品添付文書の効能・効果情報に基づいた医薬品分類方法改善の提案 